\title{
Harga Properti Residensial \& Pembiayaan Pemilikan Rumah Perbankan Syariah dan Konvensional
}

\author{
Housing Price \& Islamic and Conventional Housing Financing \\ Christine Ullyana $^{1}$, Heny K Daryanto ${ }^{2}$, Imam Teguh Saptono ${ }^{3}$ \\ ${ }^{1}$ Alumni Mahasiswa Sekolah Pascasarjana SB IPB, Email christine.ullyana@yahoo.co.id \\ ${ }^{2}$ Dosen Sekolah Pascasarjana SB IPB, Email hdaryant@mb.ipb.ac.id \\ ${ }^{3}$ Dosen Sekolah Pascasarjana SB IPB, Email itsaptono@yahoo.co.id
}

\begin{abstract}
This study investigates the dynamic relationship between macroeconomic variables and housing financing provided by convensional and islamic banking in Indonesia. Utilizing quarterly data from 2007 to 2016, this study employs Vector Error Correction Model (VECM), Impulse Response Function (IRF) and Forecast Error Variance Decomposition (FEVD). It finds that macroeconomics variables and housing price have distinct long relationship with housing financing provided by both. Our study reveal that policy intervention to stimulate or dampen housing financing provided by islamic and conventional bank can focus on GDP, house prices and monetary policy however it should be implemented to right segment. In addition, this study documents evidence that Islamic housing financing in Indonesia really dependent on interest rate. Therefore the findings suggest that Islamic Banking could apply alternative rate, possibly IHPR to manage to live up to their ideals in achieving the objectives of Shari'ah.
\end{abstract}

Keywords: dynamic relationship, housing financing, housing price, macroeconomics, VECM

\begin{abstract}
Abstrak. Tulisan ini meneliti hubungan dinamis antara variabel makroekonomi, harga properti dengan pembiayaan pemilikan rumah pada perbankan syariah dan perbankan konvensional di Indonesia. Data yang digunakan adalah data kuartalan dari tahun 2007 sampai dengan 2016 serta menggunakan metode Vector Autoregressive (VAR), Vector Error Correction Model (VECM), Impulse Response Function (IRF) and Forecast Error Variance Decomposition (FEVD). Hasil analisis mengindikasikan bahwa terdapat keterkaitan jangka panjang antara variabel makroenomi, harga properti dengan pembiayaan pemilikan rumah perbankan syariah dan konvensional dengan komposisi keterkaitan yang berbeda-beda. Dengan demikian, kebijakan intervensi untuk merangsang atau meredam pembiayaan rumah dapat menitikberatkan kepada stabilisasi harga rumah, pertumbuhan PDB dan kebijakan moneter. Selain itu walaupun secara normatif bunga merupakan hal yang dilarang dalam praktik perbankan syariah, namun hasil penelitian menunjukkan bahwa pembiayaan syariah terkait dan sensitif terhadap perubahan suku bunga acuan. Untuk itu disarankan menggunakan alternatif acuan lainnya seperti indeks harga properti agar perbankan syariah dapat menerapkan ekonomi islam yang menganut pada prinsip maqasid syariah.
\end{abstract}

Kata Kunci: harga rumah, hubungan dinamis, pembiayaan pemilikan rumah, makroekonomi, VECM

\section{Pendahuluan}

Krisis perumahan (subprime crisis) yang terjadi di Amerika Serikat tahun 2007/2008 merupakan bukti nyata akan peran besar sektor perumahan dalam siklus bisnis dan kestabilan ekonomi. Krisis ini bahkan mempengaruhi perekonomian negara-negara lain di dunia dan turut memiliki andil akan perubahan lanskap pertumbuhan ekonomi global. Hasil studi di beberapa negara menunjukkan bahwa sektor properti memiliki kaitan erat (backward \& forward linkage) dengan sekitar 240-270 industri, sub industri dan jasa namun hal ini bergantung pada tingkatan ekonomi negara tersebut. Sektor properti memiliki efek pelipatgandaan (multiplier efect) yang mendorong serangkaian aktivitas 
sektor ekonomi lain baik secara langsung dan tidak langsung seperti produk semen, kayu, kabel, pipa, furniture, keramik, jasa arsitek, jasa interior sampai jasa keuangan seperti hedge fund dan produk derivatif. Beragamnya keterkaitan tersebut menyebabkan siklus properti akan sangat signifikan mempengaruhi pertumbuhan dan keberlangsungan ekonomi suatu negara.

Secara teoritis, hubungan antara harga properti dan kredit bank dapat berjalan dua arah. Ketersediaan kredit perbankan akan meningkatkan permintaan terhadap perumahan dan sekaligus dapat meningkatkan harga perumahan, akibat suku bunga kredit yang lebih rendah sebagai sinyal atas ekspektasi kondisi ekonomi yang bagus dan kemudahan likuiditas yang dihadapi oleh rumah tangga (Oikarinen 2009). Selain itu berdasarkan studi di beberapa negara, sektor properti memiliki efek pelipatgandaan (multiplier efect) yang mendorong serangkaian aktivitas sektor ekonomi lain baik secara langsung dan tidak langsung. Beragamnya keterkaitan tersebut menyebabkan siklus properti akan sangat signifikan mempengaruhi pertumbuhan dan keberlangsungan ekonomi suatu negara. Namun disisi lain, perkembangan industri properti yang berlebihan dapat menimbulkan dampak negatif bagi perekonomian. Kondisi ini mempengaruhi kondisi keuangan perbankan melalui dua aspek yaitu terganggunya likuiditas dan nilai jaminan bank serta kinerja debitur dibidang properti.

Berkaca pada subprime mortage crisis, perhatian Bank Indonesia selaku pengambil kebijakan moneter terhadap pertumbuhan KPR dan harga properti semakin intensif. Terlebih lagi dengan adanya data pertumbuhan KPR dan kenaikan indeks harga properti residensial di pasar primer yang melampaui pertumbuhan PDB sejak tahun 2013 (Gambar 1) serta adanya tambahan informasi bahwa terdapat pembelian properti secara bulk (lebih dari 1 unit), baik menggunakan KPR ataupun secara tunai/tunai bertahap.

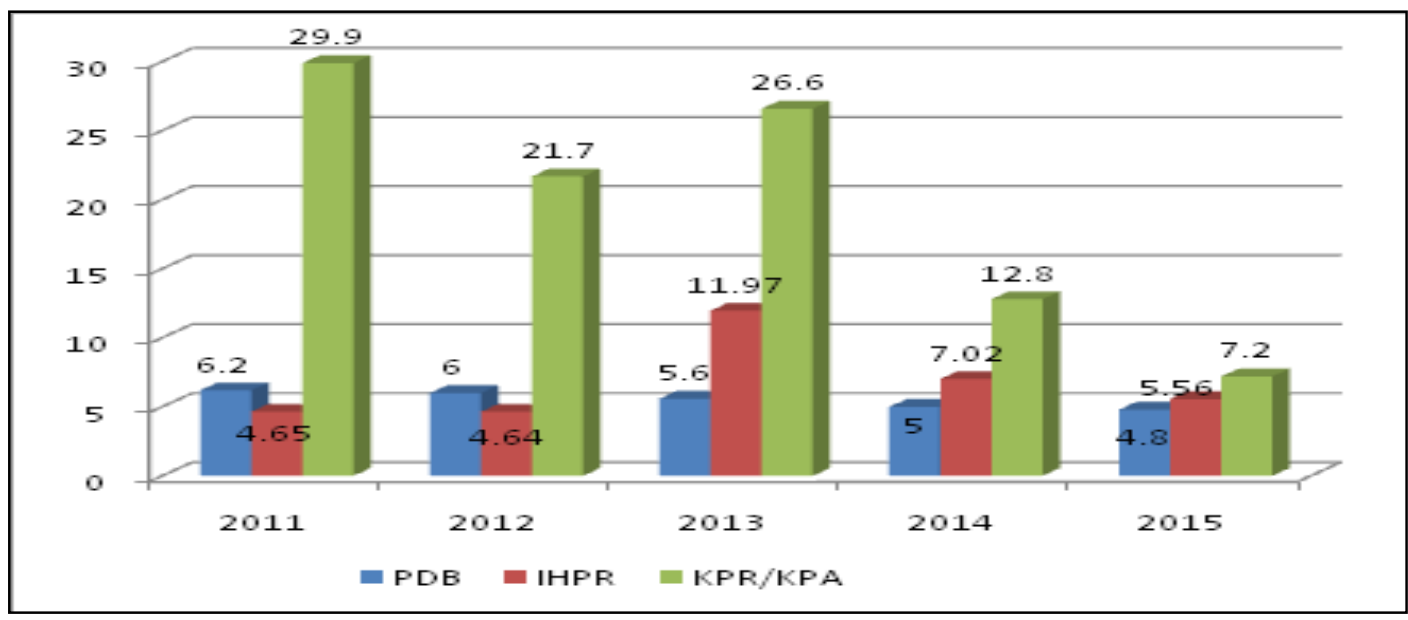

Sumber: Bank Indonesia BPS (2015)

\section{Gambar 1 Pertumbuhan PDB, Indeks Harga Properti Residensial dan outstanding kredit total KPA dan KPR di Indonesia}

Data Sistem Informasi Debitur (SID) per April 2013 menunjukkan bahwa terdapat 35.298 debitur memiliki fasilitas KPR lebih dari satu (sekitar 4.6\% dari total debitur KPR), dengan nilai baki debet Rp 31.8 T (12.4\% dari total baki debet KPR). Dengan perilaku demikian, permintaan terhadap perumahan diperkirakan akan terus meningkat dan dikhawatirkan terus mendorong kenaikan harga rumah. Untuk selanjutnya, kenaikan harga yang cukup tinggi dikhawatirkan dapat menjadi pemicu instabilitas keuangan apabila terjadi gagal 
bayar oleh masyarakat yang memanfaatkan jasa perbankan sebagai sumber pembiayaan dalam pembelian properti.

Bank Indonesia memberlakukan ketentuan tentang Loan to Value (LTV) / Financing to Value (FTV) untuk meningkatan aspek kehati-hatian bank dalam penyaluran kredit kepemilikan properti dan kredit konsumsi beragun properti sejak Juni 2012 dan terus direvisi sesuai dengan kondisi perkembangan ekonomi dan pertumbuhan kredit nasional. Namun demikian perlu dibuktikan secara empiris mengenai perilaku kredit dan pembiayaan pemilikan rumah terhadap harga properti residensial agregat dan disagregat serta kondisi makroekonomi sehingga dapat diketahui apakah kebijakan LTV yang diterapkan telah tepat sasaran dalam lingkungan sistem perbankan ganda di Indonesia. Penelitian terkait hubungan dinamis kondisi makroekonomi dan harga properti residensial dengan pembiayaan pemilikan rumah syariah dan konvensional diharapkan dapat mengisi gap informasi yang selama ini belum dilakukan penelitian secara empiris.

\section{Tinjauan Pustaka}

\subsection{Kaitan antara PDB, pembiayaan perbankan dan harga properti}

Dalam suatu sistem ekonomi modern, perbankan memiliki peran strategis dalam perekomian suatu negara (Suta \& Musa 2003). Bank berperan mengalirkan modal ke dalam perekonomian sehingga tidak ada perekonomian yang mampu berkembang tanpa peranan bank. Sebagai lembaga intermediasi, bank berpartisipasi sebagai penyandang dana dalam bentuk kredit bagi pelaku bisnis untuk mengembangkan usahanya. Karena peranan sebagai lembaga intermediasi inilah bank secara langsung maupun tidak langsung menunjang pertumbuhan ekonomi sebuah negara yang diukur dengan PDB. Peningkatan pertumbuhan PDB juga dapat dijdikan indikator bagi perbankan untuk meningkatkan penyaluran kreditnya, sehingga pertumbuhan dapat tetap terjaga.

Penelitian yang dilakukan Arestis dan Demetriades (1997) menunjukkan adanya asosiasi yang signifikan dan positif antara pembangunan sektor keuangan dengan pertumbuhan ekonomi riil di Jerman. Pembangunan sektor keuangan ini mempengaruhi pertumbuhan ekonomi melalui alokasi sumberdaya modal. Industri perbankan yang merupakan bagian dari pembangunan sektor keuangan negara akan mendistribusikan simpanan masyarakat kepada perusahaan dalam bentuk penciptaan kredit. Hal tersebut kemudian diharapkan mampu menggairahkan proses pertumbuhan ekonomi melalui peningkatan produktivitas dan mendukung aktivitas ekonomi disegala bidang. Amiruddin et al (2007) mengemukakan bahwa pembangunan dalam sektor keuangan menyebabkan pertumbuhan yang signifikan dalam jangka pendek maupun jangka panjang. Terdapat hubungan dua arah antara pembangunan keuangan dan pertumbuhan ekonomi. Pertumbuhan ekonomi yang cepat dan berkelanjutan akan didukung oleh perluasan sistem keuangan yang mampu melayani semua elemen dalam perekonomian. Pertumbuhan ekonomi juga berperan dalam mendukung sektor keuangan untuk meningkatkan transaksi dalam perekonomian yang kemudian menaikkan tabungan domestik dan menghasilkan lebih banyak transaksi.

Dari penelitian Corsetti et al. (1998) serta Bunda dan Ca'Zorzi (2009) dapat disimpulkan bahwa harga properti sangat berpengaruh pada besarnya nilai kredit yang disalurkan dan sebaliknya. Sedangkan besarnya nilai kredit mempengaruhi PDB. Pengaruh besarnya kredit terhadap PDB didukung penelitian Bunda dan Ca'Zorzi (2009) yang menunjukkan fenomena kenaikan yang bersamaan antara kredit perbankan dan PDB di negara-negara Eropa. Karena sektor perumahan mempunyai peranan besar dalam jumlah kredit yang diberikan maka naik turunnya harga dan permintaan perumahan mempengaruhi variabel makro. Penelitian Siegel (2003), Holt (2009), Lail et al. (2009), dan banyak penelitian lain 
juga menunjukkan pengaruh jatuhnya harga sektor properti terhadap krisis perekonomian. Selain itu, penelitian Otrok dan Terrones (2005), meneliti 13 negara industri, menemukan adanya efek harga rumah terhadap variable-variabel makro ekonomi. Tentu saja jika PDB terpengaruh maka kesempatan kerja, permintaan aggregate, inflasi, dan variabel makro lainnya juga ikut terpengaruh.

\subsection{Kaitan antara suku bunga, pembiayaan perbankan dan harga properti}

Para ahli ekonomi klasik mengatakan bahwa tingkat suku bunga berperan dalam menentukan besarnya tabungan dan investasi yang dilakukan dalam perekonomian (Sukirno 2002). Setiap perubahan suku bunga akan merubah jumlah tabungan rumah tangga dan investasi yang dilakukan pengusaha. Para pengusaha ini akan melakukan investasi hanya apabila tingkat pengembalian modal yang diperoleh melebihi tingkat bunga yang berlaku. Sehingga semakin rendah tingkat suku bunga maka semakin banyak investasi yang dilakukan para pengusaha dan secara tidak langsung semakin memperbesar PDB. Namun Keynes dalam Sukirno (2002) memiliki pendapat yang berbeda dari para ekonom klasik. Tingkat suku bunga bukan merupakan faktor yang dominan dalam menentukan jumlah tabungan melainkan pendapatan rumah tangga. Pendapatan rumah tangga merupakan faktor penentu dan perubahan tingkat suku bunga yang cukup besar tidak akan mempengaruhi jumlah tabungan yang akan dilakukan rumah tangga tersebut.

Selain mempengaruhi investasi dalam perekonomian, suku bunga sebagai alat moneter juga berperan dalam mengontrol jumlah uang yang beredar. Pemerintah dapat mengatur sirkulasi uang dalam perekonomian melalui kebijakan tingkat suku bunga. Semakin rendah tingkat suku bunga akan menambah jumah uang yang beredar dan sebaliknya semakin tinggi suku bunga jumlah uang yang beredar akan berkurang (Dornbusch 2004). Jumlah uang beredar ini nantinya akan mempengaruhi inflasi dan inflasi akan meningkat seiring dengan meningkatnya jumlah uang yang beredar.

Keterkaitan suku bunga dalam investasi tercermin pada perilaku perusahaan dalam pengambilan keputusan untuk mengambil kredit, ketika ekspansi perusahaan dihadapkan pada keterbatasan sumber daya kapital. Suku bunga sebagai suatu bentuk pengembalian berdampak pada pinjaman yang akan dilakukan perusahaan. Suku bunga yang menurun membuat perusahaan tertarik untuk meminjam uang dengan harapan akan mampu meningkatkan pertumbuhan ekonomi melalui peningkatan investasi. Ketika suku bunga mengalami kenaikan, perusahaan akan cenderung menahan keinginannya melakukan investasi karena tingkat pengembalian yang meningkat.

Koivo (2008) melakukan penelitian mengenai keefektifan suku bunga sebagai alat moneter di Cina dengan menganalisis efek suku bunga pada perekonomian terhadap permintaan kredit setelah dilakukannya reformasi keuangan dalam periode waktu 1998-2007. Reformasi sistem perekonomian dan perbankan serta kebijakan tingkat suku bunga diharapkan mampu mempengaruhi permintaan kredit. Penurunan tingkat suku bunga diharapkan dapat menjadi stimmulus bagi peningkatan permintaan kredit oleh invetor sehingga memberi dampak pada perekonomia di Cina. Hasil penelitian menunjukkan bahwa suku bunga menjadi faktor penting dalam permintaan kredit namun peranan yang diberikan relatif lemah dalam mendukung pertumbuhan ekonomi riil di negara tersebut. Bijapur (2009) dalam penelitiannya menganalisis efektifiktas kebijakan moneter dalam kredit pada situasi terjadinya guncangan sistem keuangan dengan mempertimbangkan rentang waktu 1972-2009 di Amerika Serikat. Hasil penelitian menunjukkan bahwa penurunan suku bunga berdampak negatif terhadap penyaluran atau permintaan kredit dan pertumbuhan PDB. Adrian dan Shin (2008) menyatakan bahwa lemahnya penyaluran kredit dalam kondisi suku bunga menurun disebabkan karena guncangan pada sistem 
keuangan yang berimbas pada penurunan modal sektor perbankan dan melakukan pembatasan dalam memberikan pinjaman.

Bunga berpengaruh terhadap permintaan rumah untuk tujuan investasi karena saat bunga turun return bersih investasi meningkat. Selain itu bunga juga berpengaruh terhadap permintaan rumah untuk tujuan konsumsi (ditempati) karena menentukan cicilan yang harus dibayar padahal cicilan yang harus dibayar signifikan dibanding cash flow keluarga. Dengan demikian jika bunga turun maka permintaan rumah akan naik dan akibatnya harga rumah naik. Penelitian Iossifov et al. (2008) menggunakan data 20 negara maju menemukan bahwa tingkat bunga jangka pendek yang diakibatkan kebijakan moneter memiliki pengaruh terhadap harga rumah tinggal. Perbankan umumnya menjadi sumber kredit perumahan. Corsetti et.al.(1998) menunjukkan hubungan antara sektor perumahan (real estate) dan perbankan di negara-nagara Asean. Penelitian mereka menunjukkan 30-40 persen total asset perbankan terpengaruh pada asset properti dan 80-95 persen jaminan (collateral) terdiri dari asset fisik seperti tanah, rumah atau pabrik. Penelitian Bunda dan Ca'Zorzi (2009) menyampaikan fenomena di Eropa, Asia, Amerika Latin, dan Afrika Selatan bahwa ada kenaikan harga properti dan jumlah kredit secara bersama-sama. Keterkaitan aktivitas perbankan dengan harga rumah juga disampaikan oleh Corsetti et al. (1998) yang menunjukkan dampak penurunan harga properti terhadap stabilitas sektor perbankan. Penurunan harga rumah berarti berkurangnya nilai asset yang dijaminkan dan telah dipegang perbankan. Perbankan akan mengalami kerugian besar jika terjadi kredit macet sedangkan nilai jaminan turun. Corsetti et al. (1998) dalam penelitiannya menyampaikan hubungan antara kerugian perbankan dengan penurunan harga properti selama krisis di Asean 1997-1998.

\subsection{Kerangka Penelitian Konseptual}

Bank Indonesia menggunakan kebijakan moneter untuk mencapai sasaran akhir yang diinginkan yaitu kestabilan ekonomi makro. Berdasarkan sistem perekonomiannya, Indonesia menganut Inflation Targetting sehingga untuk menjaga kestabilan ekonomi makro kebijakan yang diambil adalah penetapan BI Rate yang diumumkan setiap bulan yang bertujuan untuk mengendalikan inflasi. Kebijakan tersebut tidak serta merta langsung mereduksi tingkat inflasi melainkan akan menimbulkan dampak terhadap aktifitas ekonomi serta keuangan melalui transmisi kebijakan moneter yang pada akhirnya mempengaruhi kondisi makroekonomi Indonesia. Pengaruh kebijakan tersebut akan berimbas pada suku bunga, kredit, nilai tukar dan ekspektasi masyarakat.

Kebijakan moneter yang ditetapkan oleh bank sentral akan berpengaruh terhadap perkembangan berbagai aset suku bunga di sektor keuangan dan selanjutnya akan berpengaruh pada tingkat inflasi dan output riil. Dalam jangka pendek operasi moneter Bank Sentral akan mempengaruhi tingkat suku bunga jangka pendek seperti SBI. Selanjutnya perubahan ini akan memberikan pengaruh pada bunga/margin pembiayaan pemilikan rumah yang dibebankan perbankan kepada debiturnya. Tahap berikutnya, transmisi suku bunga dari sektor keuangan ke sektor riil akan tergantung pada pengaruhnya terhadap permintaan konsumsi dan investasi.

Perbankan, kondisi dan kestabilan makroekonomi serta harga properti saling mempengaruhi satu dengan yang lainnya. Sifat interaksi kausalitas antara pasar properti dan kredit juga memiliki implikasi penting bagi perekonomian. Peningkatan ketersediaan kredit cenderung akan meningkatkan permintaan akan rumah. Pertumbuhan permintaan kemudian akan tercermin dalam harga perumahan yang lebih tinggi sesuai dengan hukum permintaan dan penawaran. Disisi lain, kenaikan harga rumah juga akan memacu aktivitas penyaluran kredit perbankan.

Jurnal Al-Muzara'ah Vol.4, No.2, 2016 
Dalam sistem perbankan ganda, perubahan indikator utama makroekonomi tersebut tidak akan hanya mempengaruhi perbankan konvensional namun perbankan syariah. Hal ini karena kedua jenis perbankan tersebut berada dalam lingkungan makroekonomi yang sama. Namun respon yang dihasilkan akibat perubahan tersebut tentunya akan berbeda antara perbankan syariah dan konvensional karena prinsip operasional kedua bank tersebut berbeda. Oleh karena itu diperlukan strategi masing-masing perbankan dalam menghadapi perubahan kondisi makroekonomi tersebut

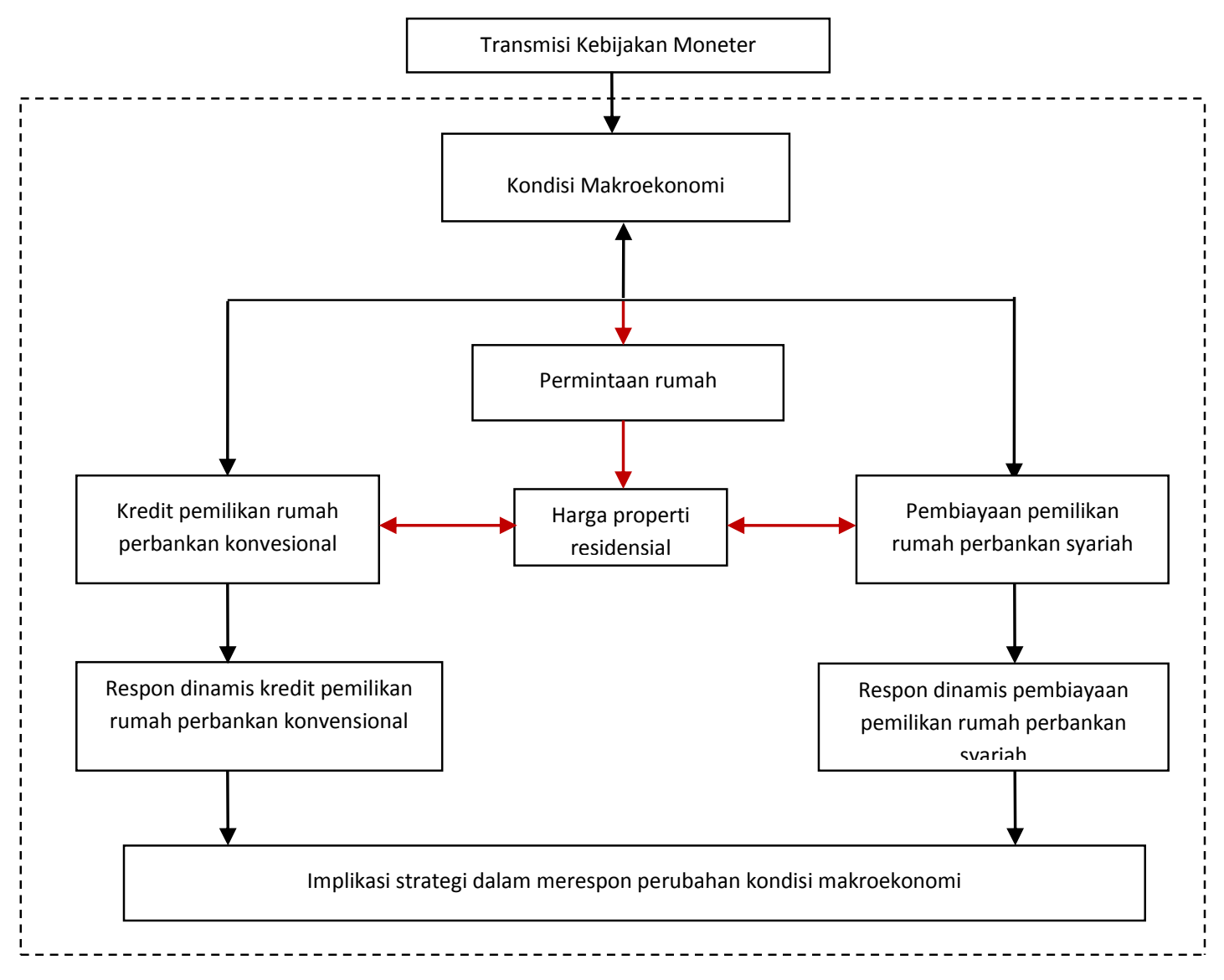

Gambar 2 Kerangka Pemikiran Penelitian

\section{Metode Penelitian}

\subsection{Jenis dan Sumber Data}

Penelitian ini menggunakan data sekunder yang meliputi data time series kuartal 1 tahun 2007 sampai dengan kuartal 1 tahun 2016s yang diperoleh dari Statistik Perbankan Indonesia (SPI) dan Statistik Perbankan Syariah (SPS) Bank Indonesia serta Badan Pusat Statistik (BPS). Data kuantitatif yang digunakan merupakan data pembiayaan konsumsi yang mewakili data pembiayaan perumahan pada perbankan syariah yang terdiri dari Bank Umum Syariah (BUS) dan Unit Usaha Syariah (UUS), data KPR Bank Umum, data Indeks Harga Properti Residensial yang merefleksikan harga properti serta data Produk Domestik Bruto dan yang terakhir adalah data BI Rate yakni variabel yang merefleksikan tingkat suku bunga acuan (lending rate). 


\subsection{Metode Pengolahan dan Analisis Data}

Metode penelitian yang digunakan adalah analisis Vector Autoregressive (VAR). Vector Error Correction Model (VECM) digunakan jika data yang digunakan tidak stationer pada tingkat level sehingga harus didiferensiasikan pada turunan pertama (first differencing) dan memiliki hubungan jangka panjang (kointegrasi). Pada analisis VAR dan VECM ada beberapa tahap yang perlu dilakukan yaitu uji stationeritas data, uji stabilitas, penentuan lag optimal, uji kointegrasi, penentuan model umum VECM, dan Innovation Accounting yang terdiri dari analisis Impulse Response Function (IRF) dan Variance Decomposition (VD).

\section{Model persamaan 1}

$\mathrm{DKPR}_{\mathrm{t}}=\mathrm{a} 0+\mathrm{a} 1 \operatorname{DKPR}_{\mathrm{t}-1}+\mathrm{a} 2 \operatorname{DIHPR}_{\mathrm{t}-1}+\mathrm{a} 3 \operatorname{DBIRATE}_{\mathrm{t}-1}+\mathrm{a} 4 \operatorname{DPDB}_{\mathrm{t}-1}+$ Coint $\left(\mathrm{KPR}_{\mathrm{t}-1}\right.$ + a5 BIRATE $\left._{\mathrm{t}-1}+\mathrm{a} 6 \mathrm{IHPR}_{\mathrm{t}-1}+\mathrm{a} 7 \mathrm{PDB}_{\mathrm{t}-1}\right)$

\section{Model persamaan 2}

DPembiayaan $_{\mathrm{t}}=\mathrm{b} 0+\mathrm{b} 1$ DPembiayaan $_{\mathrm{t}-1}+\mathrm{b} 2$ DIHPR $_{\mathrm{t}-1}+\mathrm{b} 3$ DBIRATE $_{\mathrm{t}-1}+\mathrm{b} 4$ DPDB $_{\mathrm{t}-1}+$ Coint $\left(\right.$ Pembiayaan $_{t-1}+$ b5 BIRATE $t-1+$ b6 IHPR $t-1+b 7$ PDB $\left._{t-1}\right)$

KPR adalah pembiayaan pemilikan rumah perbankan konvensional, Pembiayaan adalah pembiyaan pemilikan rumah perbankan syariah, IHPR adalah indeks harga properti residensial agregat, BIRate adalah tingkat suku bunga dan PDB adalah tingkat pertumbuhan ekonomi yang diukur menggunakan produk domestik bruto. Semua dinyatakan dalam logaritma natural kecuali suku bunga.

\section{Hasil dan Pembahasan}

\subsection{Respon dinamis guncangan variabel makroekonomi terhadap pembiayaan pemilikan rumah perbankan syariah dan konvensional}

Kebijakan moneter mempengaruhi kinerja perbankan dalam perannya sebagai lembaga intermediasi. Kebijakan yang tepat tentunya akan berdampak positif misalnya kebijakan moneter yang bersifat ekspansif akan berpengaruh terhadap peningkatan kredit perbankan (Mishkin 1998). Jumlah pembiayaan pemilikan rumah yang diberikan oleh perbankan tentunya dipengaruhi oleh beberapa variabel makroekonomi.

Gambar 3. menunjukkan hasil respon pembiayaan pemilikan rumah kedua perbankan akibat shock PDB, BI rate dan IHPR. PDB yang merupakan proxy dari pertumbuhan ekonomi memiliki pengaruh positif terhadap penyaluran pembiayaan pemilikan rumah baik di perbankan konvensional maupun syariah.

Semakin tinggi tingkat pertumbuhan ekonomi maka semakin besar pula tingkat pendapatan masyarakat sehingga akan mendorong masyarakat untuk meningkatkan konsumsi ataupun investasi termasuk pembelian rumah. Peningkatan pembelian rumah ini akan meningkatkan permintaan kredit atau pembiayaan termasuk pembiayaan pemilikan rumah di kedua perbankan. Guncangan pada variabel PDB mulai direspon secara positif pada periode kedua oleh kedua perbankan dengan proporsi yang berbeda. Perbankan syariah merespon sebesar 0,01 sedangkan perbankan konvensional hanya sebesar 0,0001. Namun memasuki periode ketiga, respon perbankan konvensional meningkat dan mulai mencapai kestabilan di periode ke empat belas sebesar 0,021. Respon perbankan syariah di periode ketiga meningkat sampai mencapai kestabilan di periode kesembilan. 
Respon Cholesky One S.D. Respon KPR terhadap PDB, Birate, IHPR

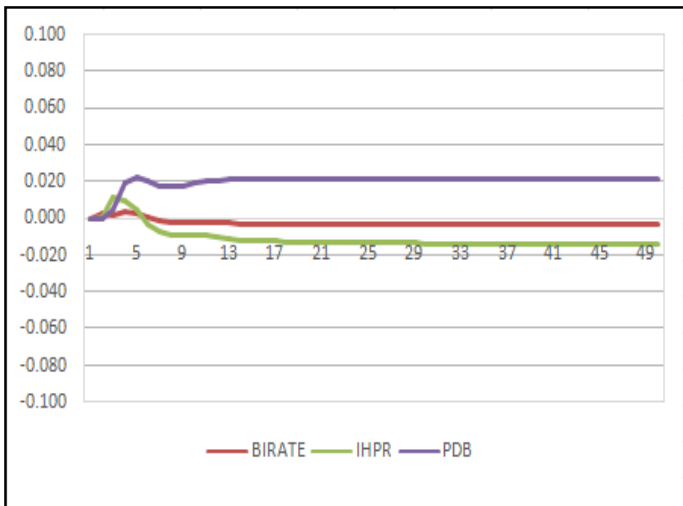

Gambar 3 Respon impuls pembiayaan pemilikan rumah bank konvensional (kiri) dan respon pembiayaan pemilikan rumah bank syariah terhadap guncangan makroekonomi (PDB, suku bunga) dan harga properti agregat

Guncangan pada harga rumah agregat langsung direspon negatif oleh pembiayaan kepemilikan rumah perbankan syariah di periode kedua di level 0,013 menjadi 0,075 di periode sepuluh namun direspon positif untuk sementara waktu oleh perbankan konvensional dari level 0.0004 di periode kedua naik sampai level 0.011 di periode ketiga dan perlahan turun sampai periode kelima. Respon positif sementara di perbankan konvensional menunjukkan adanya persepsi kekayaan rumah tangga (wealth effect). Goodhart dan Hofmann (2008) menyebutkan tiga saluran berbeda bagaimana kekayaan harga perumahan dapat mempengaruhi permintaan kredit rumah tangga. Pertama, karena nilai agunan perumahan biasanya tinggi, peningkatan harga perumahan akan melonggarkan syarat pengajuan pinjaman oleh rumah tangga. Iacoviello (2004), misalnya, membahas dampak dari peningkatan kekayaan perumahan pada kapasitas pinjaman rumah tangga melalui efek agunan. Leung (2004) memberikan ringkasan dari studi empiris menegaskan pentingnya nilai agunan perumahan. Kedua, perubahan harga perumahan mungkin memiliki efek yang signifikan terhadap persepsi kekayaan rumah tangga, peningkatan kekayaan yang dirasakan menginduksi rumah tangga untuk meningkatkan tingkat konsumsi, sehingga menambah permintaan kredit. Ketiga, pergerakan harga perumahan berdampak pada pasokan kredit melalui apa yang disebut efek neraca. Pertumbuhan harga perumahan meningkatkan nilai modal bank sehingga menambah kemungkinan dan keinginan bank untuk meningkatkan penyaluran kredit.

Namun setelah memberikan respon positif, respon kenaikan harga rumah di periode keenam mulai turun dan berubah menjadi negatif terhadap pembiayaan di perbankan konvensional. Hal ini menunjukkan bahwa rumah tangga mulai menahan untuk melakukan pembelian rumah serta memperoleh pembiayaan pemilikan rumah dari perbankan dan demikian sebaliknya. Hal ini sesuai dengan penelitian yang dilakukan oleh Wuryandani Hermanto \& Prasetya (2005) terhadap 700 sampling responden di seluruh Indonesia bahwa salah satu variabel yang signifikan berpengaruh terhadap pengajuan KPR adalah harga properti selain tingkat suku bunga, pendapatan, pajak dan inflasi. Respon perbankan syariah mencapai kestabilan di periode sepuluh dan perbankan konvesional mencapai kestabilan di periode duapuluh.

Guncangan pada suku bunga acuan langsung direspon negatif oleh perbankan syariah di periode kedua sebesar 0,009 dan mencapai kestabilan di periode kesembilan sebesar 0,033 
sampai akhir periode. Sementara perubahan suku bunga acuan tidak langsung direspon secara negatif oleh perbankan konvensional. Perbankan kovensional memberikan respon positif di periode kedua sampai dengan periode keenam. Perbankan konvensional mulai memberikan respon negatif pada periode ketujuh dan mencapai kestabilan di 0,033 di periode keduapuluhtiga. Respon positif untuk sementara waktu sepanjang enam periode awal mengindikasikan bahwa perubahan suku bunga membutuhkan waktu untuk mempengaruhi pembiayaan perbankan konvensional. Sementara respon negatif yang secara langsung diberikan oleh perbankan syariah dapat dipahami karena pembiayaan pemilikan rumah saat ini masih didominasi dengan akad murabahah. Salah satu syarat Bai' Al Murabahah yang diatur pada fatwa DSN no. 04/DSN-MUI/IV/2000 adalah bank menjual barang kepada nasabah (pemesan) dengan harga jual plus keuntungan sehingga bank harus memberitahu secara jujur harga pokok barang kepada nasabah berikut biaya yang diperlukan.

Suku bunga acuan yang ditetapkan bank sentral akan mendorong perbankan untuk meningkatkan suku bunga simpanan serta kredit. Jika dilihat dari sisi permintaan (demand side), kenaikan suku bunga acuan memiliki korelasi negatif dengan jumlah pembiayaan karena cost bunga/margin yang harus dikeluarkan oleh rumah tangga menjadi lebih tinggi. Hal ini sesuai dengan penelitian Adebola (2011) yaitu perubahan tingkat suku bunga bersifat negatif dengan pembiayaan yang diberikan oleh perbankan syariah di Malaysia.

\subsection{Kontribusi pengaruh variabel makro dan harga rumah agregat terhadap pembiayaan pemilikan rumah bank konvensional dan syariah}

Hasil yang ditunjukkan dari Variance Decomposition pada model pembiayaan pemilikan rumah perbankan konvensional dan syariah menunjukkan bahwa pembiayaan perbankan konvensional dan syariah jauh lebih berpengaruh akibat adanya guncangan dari sisi makroekonomi pada awal-awal periode. Seperti pada Gambar 3, dalam interval peramalan pada periode pertama varians pembiayaan konvensional (KPR) dan varians pembiayaan syariah (pembiayaan) sangat diperngaruhi oleh inovasi pembiayaan itu sendiri sebesar 100 persen. Variabilitas inovasi variabel makroekonomi pada perbankan konvensional mulai dirasakan pada periode kedua dengan kontribusi variabel PDB sebesar 0.002 persen. Lain halnya dengan perbankan syariah, variabilitas inovasi variabel makroekonomi juga mulai dirasakan pada periode kedua dengan kontribusi variabel suku bunga acuan sebesar 0.76 persen, harga rumah sebesar 1.72 persen dan PDB sebesar 1.28 persen.

Pada perbankan konvensional, kontribusi PDB terus tumbuh dan menjadi salah satu faktor yang dominan dari variabel makro terhadap penyaluran pembiayaan pemilikan rumah untuk jangka panjang. Pertumbuhan output menjadi benchmark bagi rumah tangga untuk melakukan pembelian rumah baik sebagai alat konsumsi (hunian) ataupun investasi. Ketika kondisi perekonomian dalam situasi yang kondusif akan menciptakan iklim investasi yang baik dan begitu pula sebaliknya jika keadaan perekonomian sedang lesu dan tidak ada upaya yang dilakukan pemerintah dalam menggerakkan perekonomian, investasi akan sulit tumbuh dan berkembang. Hingga akhir estimasi kontribusi PDB dalam pembiayaan perbankan konvensional mencapai 50 persen. Lain halnya dengan perbankan syariah, PDB bukan menjadi salah satu faktor yang dominan dengan kontribusi hanya sekitar lima persen dari periode kelima sampai dengan akhir. 
Tabel 1 Variance Decomposition model Pembiayaan Perbankan konvensional dan perbankan syariah dan harga rumah agregat

\begin{tabular}{cccccccccc}
\multicolumn{3}{l}{ VD of KPR (Agregat): } & \multicolumn{8}{c}{ VD of PEMBIAYAAN (Agregat): } \\
\hline Period & KPR & BIRATE & IHPR & PDB & Period & Pemb & BIRATE & IHPR & PDB \\
\hline 1 & 100.00 & 0.00 & 0.00 & 0.00 & 1 & 100.00 & 0.00 & 0.00 & 0.00 \\
2 & 99.54 & 0.44 & 0.01 & 0.00 & 2 & 96.23 & 0.77 & 1.72 & 1.29 \\
12 & 47.61 & 0.65 & 8.99 & 42.75 & 12 & 55.53 & 6.72 & 32.66 & 5.09 \\
24 & 36.27 & 0.91 & 14.37 & 48.45 & 24 & 48.32 & 7.70 & 38.88 & 5.09 \\
36 & 32.51 & 1.04 & 16.59 & 49.86 & 36 & 46.21 & 7.99 & 40.71 & 5.09 \\
48 & 30.75 & 1.10 & 17.65 & 50.50 & 48 & 45.20 & 8.13 & 41.58 & 5.09 \\
50 & 30.54 & 1.11 & 17.78 & 50.57 & 50 & 45.08 & 8.14 & 41.68 & 5.09 \\
\hline
\end{tabular}

Debitur yang rasional akan menggunakan sumber pembiayaan yang jauh lebih murah artinya ketika terjadi kenaikan suku bunga akan direspon terhadap turunnya permintaan pembiayaan. Pada Gambar 13 terlihat bahwa suku bunga bukan merupakan variabel yang dominan. Hal ini mengindikasikan bahwa suku bunga bukanlah suatu hal yang sensitif bagi debitur perbankan konvensional sehingga tinggi rendahnya suku bunga tidak terlalu mengakibatkan naik turunnya permintaan pembiayaan pemilikan rumah. Variabel tersebut hanya merupakan salah satu variabel yang dipertimbangkan baik dalam fungsi penawaran maupun permintaan terhadap suatu pembiayaan. Berbeda dengan perbankan syariah dimana suku bunga memiliki kontribusi yang terus bergerak naik dari 0.7 persen di periode kedua menjadi delapan persen di akhir periode.

Varians harga rumah merupakan variabel yang dominan bagi perbankan syariah dengan kontribusi 1.7 persen di periode kedua dan terus mengalami kenaikan menjadi 41 persen di akhir periode. Namun sebaliknya bagi perbankan konvensional, harga rumah hanya berkontribusi sekitar 0.01 persen di periode kedua hingga 17.7 persen di akhir periode.
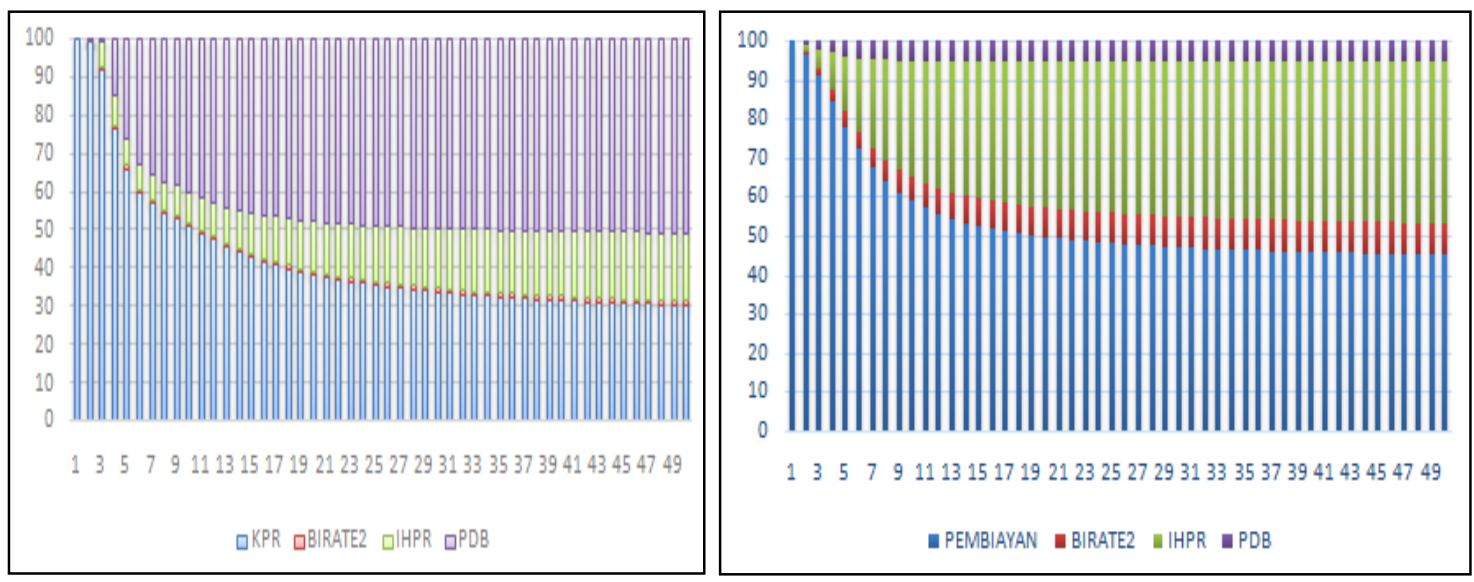

Gambar 4 Variance Decomposition model pembiayaan pemilikan rumah perbankan Konvensional (kiri) dan perbankan syariah (kanan) 
Berdasarkan semua data tersebut dapat disimpulkan bahwa variabel yang memiliki kontribusi dominan pada pembiayaan pemilikan rumah syariah adalah pembiayaan itu sendiri, harga rumah serta suku bunga sedangkan variabel yang memiliki kontribusi dominan pada pembiayaan pemilikan rumah konvensional adalah PDB, pembiayaan itu sendiri dan harga rumah. Hal ini mengindikasikan bahwa pembiayaan pemilikan rumah perbankan syariah berkaitan erat dengan sektor riil karena pembiayaan pembelian rumah yang diberikan adalah untuk tujuan konsumsi (ditempati) sementara pembiayaan pemilikan rumah konvensial cenderung untuk investasi. Seiring dengan peningkatan pendapatan yang diterima oleh rumah tangga maka rumah tangga akan meningkatkan konsumsi dan investasi, termasuk pembelian rumah sebagai alternatif investasi. Suku bunga tidak lagi menjadi variabel penting yang dipertimbangkan karena rumah tangga mengharapkan keuntungan akan kenaikan harga rumah lebih besar dibandingkan cost suku bunga yang dibayarkan (motif spekulasi).

Disisi lain, peningkatan pertumbuhan PDB menjadi salah satu katalis bagi perbankan konvensional untuk meningkatkan penyaluran pembiayaannya sehingga rumah tangga akan semakin mudah untuk mendapatkan dana dan semakin mendorong tingkat konsumsi dan investasi demikian seterusnya. Adanya kenaikan permintaan akan rumah tentunya akan mendorong kenaikan harga rumah berdasarkan hukum demand dan supply.

\section{Kesimpulan dan Saran}

\subsection{Kesimpulan}

Pembiayaan pemilikan rumah pada kedua perbankan dalam jangka panjang memberikan respon negatif akan guncangan suku bunga acuan. Penurunan suku bunga acuan akan mendorong permintaan rumah baik untuk tujuan konsumsi (ditempati) maupun investasi yang pada akhirnya akan meningkatkan permintaan akan pembiayaan pemilikan rumah di kedua perbankan. Hal ini disebabkan perbankan masih menjadi sumber utama pendanaan dalam transaksi pembelian rumah.

Guncangan pada PDB direspon positif oleh pembiayaan di kedua perbankan, konvensional dan syariah. Semakin tinggi tingkat pendapatan masyarakat akan meningkatkan kekayaan rumah tangga dan meningkatkan kemampuan pembayaran kewajiban. Peningkatan penghasilan yang dirasakan akan mendorong masyarakat untuk meningkatkan konsumsi dan investasi baik berupa rumah sebagai alternatif investasinya. Peningkatan permintaan akan rumah tentunya juga akan menambah permintaan pembiayaan di kedua perbankan. Guncangan pada harga rumah agregat direspon positif sesaat oleh pembiayaan perbankan konvensional namun lansung direspon negatif oleh pembiayaan syariah dalam jangka panjang.

Pembiayaan pemilikan rumah syariah lebih stabil dibandingkan permbiayaan pemilikan rumah konvensial. Dan walaupun secara normatif bunga merupakan hal yang dilarang dalam praktik perbankan syariah, namun secara empiris terbukti bahwa pembiayaan syariah sangat terkait dan sensitif terhadap perubahan suku bunga acuan. Dan untuk menghindari naiknya non performing loan/facility, kedua perbankan harus fokus kepada faktor internal seperti proses loan review dan pengawasannya serta lebih berhati-hati terhadap perubahan suku bunga acuan, harga properti dan gejolak pertumbuhan ekonomi.

Temuan ini memiliki implikasi penting bagi perbankan, perekonomian maupun bagi bisnis properti. Pergerakan harga rumah dan pembiayaan pemilikan rumah pada kedua perbankan akan berisi informasi tentang fluktuasi ekonomi jangka pendek. Selain itu, karena kenaikan suku bunga kemungkinan akan menekan tingkat penyaluran 
pembiayaan perbankan, maka otoritas moneter harus mewaspadai implikasi atas kebijakan yang dibuat. Hasil penelitian ini juga menunjukkan bahwa transmisi kebijakan moneter pada kredit perbankan, yang kemudian berinteraksi dengan harga rumah akan memicu fluktuasi output jangka pendek. Akhirnya, hasil penelitian ini diharapkan dapat menjadi masukan dan perhatian untuk pemegang otoritas kebijakan moneter untuk memastikan stabilitas ekonomi dan menghindari gejolak seperti halnya krisis subprime mortgage yang terjadi di Amerika Serikat.

\subsection{Saran}

Penelitian ini menjadi sebuah awalan untuk pengembangan penelitian selanjutnya agar analisis yang ditelaah lebih mendalam. Kajian ini menggunakan data agregat pembiayaan pemilikan rumah baik untuk perbankan syariah dan konvensional sehingga respon yang dihasilkan adalah respon pembiayaan nasional. Indonesia saat ini memiliki 35 provinsi dengan kondisi demografi, tingkat pendapatan daerah serta pertumbuhan harga properti yang berbeda antara provinsi satu dengan yang lain. Oleh karena itu untuk mendapatkan hasil yang lebih baik diharapkan penelitian selanjutnya dapat mempertimbangkan hal-hal tersebut sehingga dapat diketahui respon pembiayaan di setiap provinsi secara lebih mendetail. Selain itu perluasan penelitian terhadap perilaku konsumen serta pertimbangan pengajuan pembiayaan pemilikan rumah baik di perbankan konvensional maupun perbankan syariah baik di segmen rumah kecil, menengah dan besar juga dapat dilakukan untuk memperkaya khasanah pembahasan. Dan dengan keterbatasan data yang tersedia pada penelitian ini, perluasan bahasan terkait inlfasi, Dana Pihak Ketiga (DPK), suku bunga/bagi hasil penempatan pihak ketiga serta keterkaitan kebijakan makroprudensial juga baik untuk dilakukan agar hasil penelitian selanjutnya dapat lebih terlihat dengan jelas, jenis pembiayaan mana yang ternyata lebih dipengaruhi dengan adanya gejolak dari sisi eksternal/makroekonomi dan kebijakan makroprudensial sehingga strategi yang direkomendasikan lebih bersifat spesifik.

\section{Daftar Pustaka}

Bank Indonesia., Statistik perbankan Indonesia, Bank Indonesia (2013).

Bunda, Irina., Michele, Ca'Zorzi., Signal from Housing and Lending Booms. Working Paper Series No 1194. European Central Bank (2009).

Buiter, Willem., Housing wealth isn't wealth. Economic. Vol.3, 2010-22 (2010).

Collyns, C., Senhadji, A., Lending booms, real estate bubbles and the Asian crisis. IMF working paper (2002).

Gerlach, S.,Wensheng, Peng., Bank Lending and Property Prices in Hong Kong, Journal of Banking \& Finance, 29 (2), 461-481 (2005).

Goodhart, C., Hofmann, B., House prices, money, credit, and the macroeconomy. Oxford Review of Economic Policy, 24(1), 180-205 (2008).

Hofmann, B., Bank lending and property prices: Some international evidence, The Hong Kong Institute for Monetary Research Working Paper No. 22 (2003).

Hofmann, B., The determinants of private sector credit in industrialized countries: do property prices matter? International Finance. 7, 203-234 (2004).

Ibrahim, M. H., Law , S. H., House prices and bank credits in Malaysia: An aggregate and disaggregate analysis, Habitat International 42 (2014) 111-120 (2014).

Ibrahim, M.H., Stock Prices and Bank Loan Dynamics in a Developing Country: The Case of Malaysia, Journal of Applied Economics 9, no. 1 : 71-89 (2006).

Inoguchi, M., Influence of real estate prices on domestic bank loans in Southeast Asia. Asian-Pacific Economic Literature 25(2), 151-164 (2011). 
Kassim, S. H., M.S.A. Majid, \& R.M. Yusof., Impact of Monetary Policy Shocks on the Conventional and Islamic Banks in a Dual Banking System: Evidence from Malaysia, Journal of Economic Cooperation and Development 30, no. 1: 41-58 (2009).

Gerlach, S., W. Peng., Bank Lending and Property Prices in Hong Kong, Journal of Banking and Finance 29, no. 2:461-81 (2005).

Oikarinen, E., Interaction between house prices and household borrowing: the Finnish case. Journal of Banking and Finance. 33, 747-756 (2009).

Setianto, Rahmat., Harga properti residensial dan kredit perbankan di Indonesia: analisa agregat dan dis-agregat. Jurnal Manajemen Indonesia. Vol 15-no 1 (2015).

Wibowo M., Analisis Faktor-faktor Makro Ekonomi terhadap Pembiayaan Bank Syariah di Indonesia dan Malaysia [Tesis]. Bogor(ID): Institut Pertanian Bogor (2014).

Wuryandani, Hermanto., Prasetya., Perilaku Pembiayaan dalam Industri Properti. Bank Indonesia (2015).

Zhu, H., The structure of housing finance markets and house prices in Asia. BIS Quarterly Review. 55-69 (2006). 